\title{
Associations between Mesodinium rubrum and cryptophyte algae in the Columbia River estuary
}

\author{
Tawnya D. Peterson ${ }^{1,2, *}$, Rachel L. Golda ${ }^{1,2}$, Michael L. Garcia ${ }^{1,2}$, Binglin Li $^{1{ }^{1,2}}$, \\ Michelle A. Maier ${ }^{1,2}$, Joseph A. Needoba ${ }^{1,2}$, Peter Zuber ${ }^{1,2}$ \\ ${ }^{1}$ Institute of Environmental Health, Division of Environmental and Biomolecular Systems, Oregon Health \& \\ Science University, 20000 NW Walker Rd., Beaverton, Oregon 97006, USA \\ ${ }^{2}$ Science and Technology Center for Coastal Margin Observation and Prediction, 20000 NW Walker Rd., Beaverton, \\ Oregon 97006, USA
}

\begin{abstract}
Recurring blooms of the photosynthetic ciliate Mesodinium rubrum (= Myrionecta rubra) are observed each summer in the Columbia River estuary. Although cultured isolates of $M$. rubrum have been shown to consume cryptophyte prey during growth, the feeding behavior of M. rubrum in the field is poorly known. In the present study, a 3 mo time series of observations from a locale of putative bloom formation (Ilwaco harbor in Baker Bay, WA) showed that cryptophytes were present at relatively high abundance prior to and during $M$. rubrum blooms and declined with M. rubrum abundance. During 3 years of observation (summers of 2009, 2010, and 2011), we observed M. rubrum cells bearing numerous cryptophytes attached to the cirri throughout the estuary, especially during the bloom initiation phase and particularly in the peripheral bays. We performed a laboratory investigation in 2011 in which cryptophyte prey were introduced to high-density red-water samples in aquarium tanks. Within $2 \mathrm{~h}$, individual $M$. rubrum cells collected multiple cryptophytes on their cirri, likely as a precursor to ingestion. The cells ceased their jumping motion and instead exhibited an undulation of the cirri and drifted slowly. We hypothesize that the availability and type of cryptophyte prey is important for bloom formation and that the acquisition of several cryptophytes at once by $M$. rubrum may be indicative of its ability to 'gather' or concentrate cryptophytes from the environment.
\end{abstract}

KEY WORDS: Aquatic protists · Mesodinium rubrum - Teleaulax amphioxeia Columbia River estuary $\cdot$ Ciliate $\cdot$ Cryptophyte $\cdot$ Predator-prey

\section{INTRODUCTION}

Mesodinium rubrum (Lohmann, 1908) Hamburger \& Buddenbrock 1911 (=Myrionecta rubra) is a marine planktonic ciliate that is functionally an autotroph due to the presence of numerous cryptophyte-derived chloroplasts within the cell (Hibberd 1977, Crawford 1989), which were initially described as 'incomplete endosymbionts' (Parsons \& Blackbourn 1968, Taylor et al. 1971, Oakley \& Taylor 1978). The origin of $M$. rubrum chloroplasts is still under debate. Attempts to cultivate M. rubrum were unsuccessful until an Antarctic isolate was grown in the presence of the cryptophyte Teleaulax acuta, which were rapidly consumed (but not digested) by the ciliate $(\sim 80 \%$ reduction in prey concentrations in $48 \mathrm{~h}$; Gustafson et al. 2000). The strain did not exhibit sustained growth in the absence of cryptophyte prey. The Antarctic M. rubrum isolate consumed the prey and sequestered their nuclei, chloroplasts, and mitochondria, keeping the nucleus transcriptionally active in a process coined karyoklepty (Johnson et al. 2007). Johnson et al. (2007) demonstrated that the nuclei of the cryptophyte prey can be retained for up to $30 \mathrm{~d}$, that the nuclei remain transcriptionally active following ingestion, and that they are able to regu- 
late gene expression in plastids from multiple cryptophyte prey within the cell. The expression of nuclearencoded plastid genes declined as the number of sequestered nuclei disappeared from the population, suggesting that periodic consumption of prey is required by the ciliate to maintain chloroplast function (Johnson et al. 2007). Plastid sequestration is commonly observed in ciliates (Stoecker et al. 1988) and has recently been confirmed in the dinoflagellate Dinophysis caudata (Minnhagen et al. 2011).

In contrast, Danish isolates of Mesodinium rubrum maintained the same number of chloroplasts over several divisions in culture, leading Hansen \& Fenchel (2006) to reject the karyoklepty hypothesis in favor of the presence of a permanent endosymbiont. Since it has been clearly demonstrated that they are capable of - and that at least some isolates appear to require - feeding to sustain rapid growth, it has been suggested that $M$. rubrum depends on periodic ingestion of cryptophyte algae to sustain high growth rates (Johnson 2011). Thus far, both Korean (Park et al. 2007) and Danish (Hansen et al. 2012) M. rubrum isolates have exhibited a preference for cryptophytes of the Teleaulax/ Plagioselmis/ Geminigera clade to sustain maximal growth rates. These data indicate that the availability of appropriate prey taxa may be important in the initiation and development of $M$. rubrum blooms.

Mesodinium rubrum varies considerably in its morphology, and it has long been suggested that the taxon may represent a multi-species complex (Lindholm 1985), with support from morphological (Garcia-Cuetos et al. 2012) and molecular data (Herfort et al. 2011a, Garcia-Cuetos et al. 2012). Indeed, it has recently been shown that new varieties, including M. chamaeleon (Moestrup et al. 2012) and M. major (Garcia-Cuetos et al. 2012), represent distinct species based on differences in morphology, lifestyle, and genetic make-up. Five genetic variants all bearing plastids from the cryptophyte Teleaulax amphioxeia were identified according to differences in rRNA gene sequences (Variants A to E) in the Columbia River estuary, USA, with another identified from Danish waters (Variant F; Garcia-Cuetos et al. 2012). In the former, only one (Variant B) appears to be associated with the formation of expansive redwater blooms (Herfort et al. 2011a).

Mesodinium rubrum lacks a fully developed cytostome, or oral cavity, allowing ciliates to feed through phagocytosis (Lindholm et al. 1988). Yet, feeding has been clearly demonstrated in the species (e.g. Gustafson et al. 2000). A recent study showed the process of prey ingestion in M. rubrum (Yih et al.
2004). Although not commonly observed in $M$. rubrum populations (Small \& Lynn 1985, Hansen \& Fenchel 2006), bifurcate anterior tentacles have been shown to play an important role in feeding (Lindholm 1985, Lindholm et al. 1988, Yih et al. 2004). A loss of the tentacles may be an artifact of examining the cells under a microscope (Garcia-Cuetos et al. 2012). Nevertheless, in M. rubrum, the anterior tentacles have been shown to capture a prey item following detection of a hydromechanical signal, similar to the mechanism observed in M. pulex (Jakobsen et al. 2006), a closely related heterotrophic ciliate. The anterior tentacles are associated with a number of extrusomes (Lindholm et al. 1988), which often secrete cell contents or mucilaginous material (Rosati \& Modeo 2003). Once captured, cryptophytes are carried toward a rudimentary cytostome at the oral end of the ciliate, where they are then engulfed in a clear pouch-like area one at a time and assimilated in a timeframe of $\sim 90 \mathrm{~s}$ (Yih et al. 2004).

Aside from its unusual cytological features, Mesodinium rubrum is of considerable interest due to the fact that it forms expansive red-water blooms in estuaries, fjords, and upwelling systems worldwide (Taylor et al. 1971, Lindholm 1985). Annually recurring 'red-water' blooms have been reported in the Southampton estuary, UK (Soulsby et al. 1984), and elsewhere, including the Columbia River estuary, USA (Herfort et al. 2011a,b). In the latter, blooms typically form in the late summer and autumn, where M. rubrum proliferates in dramatic and extensive red-water patches. These red-water patches are hotspots of biological and biogeochemical activity: they are associated with elevated bacterial production, elevated particulate organic carbon and nitrogen, low dissolved nutrients, and high dissolved organic nutrients (Herfort et al. 2012). The coincidence between high densities of $M$. rubrum with low dissolved inorganic nutrients (Herfort et al. 2012) and levels of oxygen supersaturation of up to $175 \%$ (Roegner et al. 2011) suggests that Columbia River M. rubrum variants exhibit high rates of photosynthesis during blooms. The ciliate is highly motile and phototactic (Smith \& Barber 1979, Crawford \& Purdie 1992, Fenchel \& Hansen 2006, Jiang 2011), and they are known to exhibit strong vertical migration (Crawford \& Lindholm 1997), which might help to explain how they are able to bloom in rapidly flushed systems, such as the Columbia River estuary, where water residence times are $<5 \mathrm{~d}$ (Neal 1972).

Between 2009 and 2011, we observed specimens of Mesodinium rubrum from the Columbia River estuary that bore numerous cryptophytes attached to 
their cirri, polykinetids composed of $>2$ kinetosomes plus cilia and associated structures (Corliss 1979). We hypothesize that the attachment of the cryptophytes to the cirri is a means of prey capture and is therefore a precursor to the ingestion and assimilation of prey items. Since the behavior of organisms in the laboratory is often - though necessarily - confounded by artifacts to some degree, it is important to report pertinent field observations when possible. Here, we share some observations of $M$. rubrum-cryptophyte interactions from field samples in an estuarine environment where recurrent large blooms occur. In addition, we show a time series of observations of cryptophytes and M. rubrum from a peripheral bay in the Columbia River estuary leading up to the initiation of the annual bloom in 2011 to provide insight into the prey availability and feeding behavior of $M$. rubrum in the field. To our knowledge, the particular physical associations between free-living cryptophytes and $M$. rubrum that we observed in the Columbia River estuary have not previously been reported in the region or elsewhere. These observations offer insights into potential prey involvement in the dynamics of bloom initiation and development of $M$. rubrum. In addition, taxonomic differences among $M$. rubrum variants (or within the species complex) may be related to different modes of prey capture and feeding; thus, these observations may contribute to a better understanding of potential relationships between prey dynamics and niche differentiation within the M. rubrum species complex.

\section{MATERIALS AND METHODS}

\section{Study area}

The Columbia River estuary is a drowned river valley with a geometry that is long and narrow (Frey et al. 1984), and it has a short water residence time on the order of 1 to $5 \mathrm{~d}$ (Neal 1972). There are 2 main channels in the estuary (north and south); the south channel is the main navigation channel through which most of the freshwater flows are directed, while the north channel receives the majority of incoming marine waters during the flood tide (Jay 1984). While circulation is rapid in the estuary proper, 4 peripheral bays exhibit slightly more sluggish circulation: Baker Bay, which lies at the seaward end of the estuary (north), Youngs Bay, the southern seaward end of the estuary, Grays Bay at the northeastern end of the estuary, and Cathlamet Bay at the southeastern end of the estuary (Jay 1984; Fig. 1).

\section{Sample collection}

Sampling was conducted in 2 peripheral bays (Baker Bay and Youngs Bay) and in the estuary's main channels either from ships (MV 'Forerunner' or RV 'Sailfin') or from a floating pier at Ilwaco harbor in Baker Bay during the summer and early autumn (June to October) (for sampling locations, see Fig. 1). Sampling from the MV 'Forerunner' took place on July 21, 2009, and again on August 6, 2009, when samples for Mesodinium rubrum were collected at 1 to $2 \mathrm{~m}$ depth into 101 Niskin bottles (General Oceanics) lowered to the surface using a winch and gently dispensed into 7.61 acid-cleaned polycarbonate containers for transport back to the laboratory in coolers packed with blue ice. Sampling from the RV 'Sailfin' and from the floating pier took place during the summer and autumn of 2011.

To identify potential relationships between Mesodinium rubrum and its cryptophyte prey in the field, a time series of observations was conducted in Ilwaco harbor in Baker Bay, WA (2009 to 2011), the putative initiation site for recurring expansive blooms (Herfort et al. 2011b). Whole water samples were collected either from the surface $(0$ to $0.5 \mathrm{~m}$ ) into a clean 7.61 polycarbonate carboy at the float-

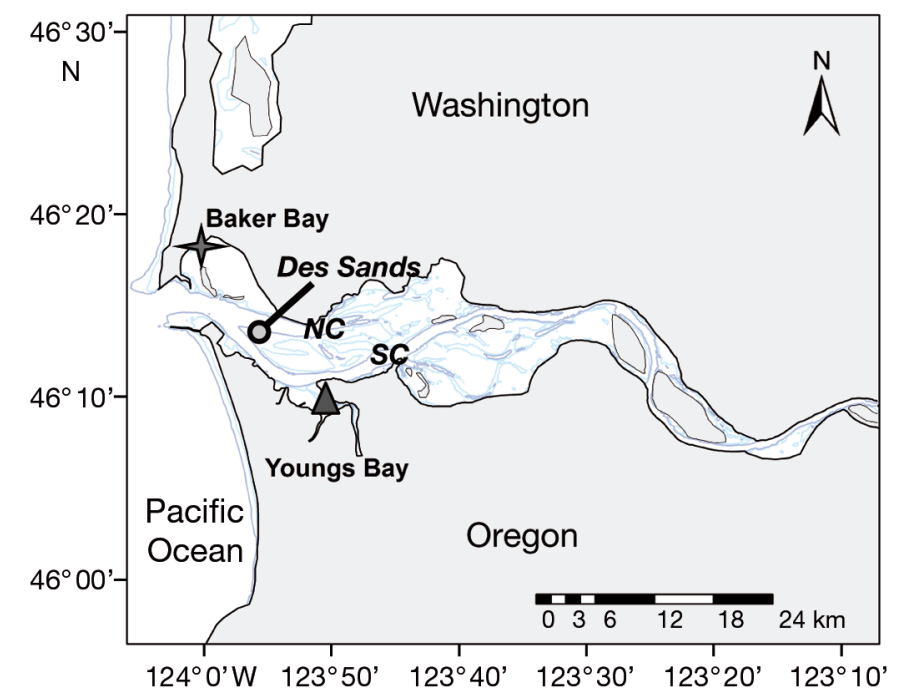

Fig. 1. Study area, showing locations of red-water collection at Desdemona Sands (Des Sands) between the estuary's north and south channels (NC and SC), Youngs Bay, a peripheral bay in the south estuary, and Baker Bay, a peripheral bay in the north. Two additional peripheral bays (Grays Bay and Cathlamet Bay) are not indicated, but they are the bays to the north (Grays Bay) and south (Cathlamet Bay) at the eastern end of the estuary. The 3 sampling sites are shown: Ilwaco harbor (4-point star; in Baker Bay), Desdemona Sands (grey circle), and Youngs Bay (filled triangle) 
ing pier at Ilwaco harbor (August 24, 2011) for transport back to the shore-based laboratory, or else they were collected from near the surface (1 to $2 \mathrm{~m}$ ) aboard the RV 'Sailfin' using a 2.2 l Van Dorn bottle (Lab Safety Supply), which was subsequently dispensed into 7.61 polycarbonate carboys (September 1 to October 27,2011).

In addition to the time series conducted at Ilwaco harbor, several north-south (i.e. cross-estuary) and east-west (i.e. along-estuary) transects were conducted aboard the RV 'Sailfin' in September and October 2011 to track the development of Mesodinium rubrum blooms within a spatial context that included the estuary's main channels as well as the 2 seaward peripheral bays (Baker Bay and Youngs Bay). Samples were collected several times throughout the summer at Ilwaco harbor, in the main channels of the Columbia River estuary (i.e. north and south channels), in Youngs Bay, OR, in the southwestern region of the estuary, and between the main channels in a shallow area known as Desdemona Sands (Fig. 1). Like the collection procedure described above for the Ilwaco harbor series, water samples were collected along the transects from a depth of 1 to $2 \mathrm{~m}$ using a 2.2 1 Van Dorn bottle or from a surface bucket $(0 \mathrm{~m})$. Water was collected from Youngs Bay and Desdemona Sands because that is where red waters were observed on September 28 and October 6, respectively; these sites were not systematically sampled during the along-estuary transect at other times during the summer surveys.

\section{Field observations: microscopy and cell enumeration}

Once in the laboratory, the cells were examined live to observe their swimming behavior and appearance. Live cells were examined using an inverted light microscope with IMC illumination (Leica DMIL) in glass or plastic petri dishes. The live Mesodinium rubrum cells were very active, exhibiting rapid jumping rates, and therefore, they were difficult to photograph. Live cells were transferred to Utermöhl counting chambers and examined at $200 \times$ magnification under an inverted epifluorescence microscope using a Cy3 filter set (546/12 nm excitation maximum, emission detection from 575 to $640 \mathrm{~nm}$; Zeiss ApoTome). Images were captured using a microscope-mounted camera (Zeiss AxioCam). Samples were also preserved with $0.5 \%$ glutaraldehyde for further examination under epifluorescence illumination at $400 \times$ magnification.
For enumeration of Mesodinium rubrum and cryptophytes in the Ilwaco harbor time series (August 24 to October 27, 2011), water samples (50 ml) were fixed with glutaraldehyde (final conc. $0.5 \%$ ) and stored in the dark at $4{ }^{\circ} \mathrm{C}$. An aliquot of each sample (25 ml) was filtered onto a $25 \mathrm{~mm}$ diameter $3 \mu \mathrm{m}$ polycarbonate filter using gentle vacuum pressure $(<100 \mathrm{~mm} \mathrm{Hg})$. The filter was then mounted onto a glass slide with Type FF immersion oil. Using an inverted epifluorescence microscope (Zeiss ApoTome), a minimum of 200 total M. rubrum cells and free-living cryptophytes $>5 \mu \mathrm{m}$ were counted in duplicate (under 100× and 400× magnification, respectively) for each Ilwaco harbor time series ample. If the cell density of $M$. rubrum or cryptophytes was $<10$ cells $\mathrm{ml}^{-1}$, then the whole slide was examined. A second sample collected using the Van Dorn sampler aboard the RV 'Sailfin' cruises (September 1 to October 27, 2011) was fixed in Lugol's iodine (final conc. $\sim 1 \%$ ). Counts of these samples were performed to assess the potential variability between the surface ( $0 \mathrm{~m}$, collected using a bucket) and near-surface ( 1 to $2 \mathrm{~m}$ ) depths, to look for freeliving cryptophytes smaller than $5 \mu \mathrm{m}$, and to corroborate the epifluorescence counts using a different method (i.e. using Utermöhl settling chambers).

From the pier-based samples in Baker Bay (Ilwaco harbor), images of Mesodinium rubrum were captured using an imaging flow cytometer (FlowCAM, Flow Cytometer And Microscope, Fluid Imaging). Prior to running the samples through the FlowCAM, they were filtered through a $300 \mu \mathrm{m}$ nitex mesh to remove particles that could clog the flow cell. The samples were run through a $100 \mu \mathrm{m}$ flow cell at a flow rate of $0.3 \mathrm{ml} \mathrm{min}^{-1}$ and viewed using a $10 \times$ objective, and the images were captured using chlorophyll fluorescence as a trigger.

\section{Laboratory time series observations of Mesodinium rubrum-cryptophyte associations}

Initial observations indicated that Mesodinium rubrum with attached cryptophytes were present in samples collected within the lateral bays (Baker Bay and Youngs Bay) as well as in the estuary proper (Table 1). To try to elucidate whether $M$. rubrum cells were actively acquiring cryptophytes, we performed 2 time series experiments using red water collected from the field and brought back to the laboratory. In each case, the water was collected into a 201 carboy, brought back to the laboratory, and stored in an environmental chamber at $15^{\circ} \mathrm{C}$ on a $12 \mathrm{~h}$ light: $12 \mathrm{~h}$ dark 
Table 1. Percentage of Mesodinium rubrum specimens bearing attached cryptophytes in the Ilwaco harbor (Baker Bay) time series and in 2 red-water bloom patches in Youngs Bay and the estuary proper (over Desdemona Sands). Dates given as $\mathrm{mm} / \mathrm{dd}$

\begin{tabular}{|lcc|}
\hline Site & $\begin{array}{c}\text { Date } \\
(2011)\end{array}$ & $\begin{array}{c}\text { \% M. rubrum specimens } \\
\text { with attached cryptophytes }\end{array}$ \\
\hline Ilwaco harbor & $09 / 01$ & 4.0 \\
Ilwaco harbor & $09 / 14$ & 0.63 \\
Ilwaco harbor & $09 / 21$ & 30.4 \\
Ilwaco harbor & $09 / 28$ & 20.9 \\
Ilwaco harbor & $10 / 06$ & 0 \\
Youngs Bay & $09 / 28$ & 3.5 \\
Desdemona Sands & $10 / 06$ & 0.45 \\
\hline
\end{tabular}

cycle (with darkness from 19:00 to 07:00 h) between $\sim 17: 00$ and $\sim 08: 30 \mathrm{~h}$. In the first time series, water was collected from a red-water patch in Youngs Bay (Fig. 1) on September 28, 2011. The second time series was conducted using water from the estuary proper over the shallow Desdemona Sands (October 6 , 2011). The water was collected at these locations since this was where red-water patches were observed. In both experiments, $\sim 181$ of red water with abundant $M$. rubrum (mean \pm SD: $1526 \pm 71$ cells ml ${ }^{-1}$ in Youngs Bay and $541 \pm 175$ cells ml$^{-1}$ at Desdemona Sands; Table 2) from the Columbia River estuary was collected into $20 \mathrm{l}$ carboys from the surface using a clean bucket. The initial abundances of cryptophytes in each of the red-water patches were $10 \pm 3$ cells ml${ }^{-1}$ in Youngs Bay and $9 \pm 5$ cells ml $^{-1}$ at Desdemona Sands. Approximately 161 was gently transferred into a 10 gallon ( 38 l) aquarium tank in the laboratory for the experimental observations. The cells were allowed to settle under $\sim 100 \mu \mathrm{mol}$ photons $\mathrm{m}^{-2} \mathrm{~s}^{-1}$ light provided by full-spectrum lighting in each case. Once the waters had settled in the tank ( 30 min to $1 \mathrm{~h}$ ), the $M$. rubrum cells began to collect in dense aggregations within the aquarium. Aggregation was observed both in the water collected in Youngs Bay (September 28) and over Desdemona Sands (October 6).
In the first time series experiment (using Youngs Bay water), $\sim 40 \mathrm{ml}$ of a dense culture of Geminigera cryophila $\left(50000\right.$ cells $\left.\mathrm{ml}^{-1}\right)$ was added via $10 \mathrm{ml}$ plastic serological pipette to the aquarium tank at the end opposite to where the densest Mesodinium rubrum patch $\left(1983 \pm 1464\right.$ cells ml $^{-1}$ as determined just prior to the addition of cryptophytes in the experiment, i.e. nearly $20 \mathrm{~h}$ after the sample was collected) was observed. Following the addition of cryptophytes into the tank, we observed changes in the number and frequency of cryptophytes attached to M. rubrum cirri. Samples $(\sim 40 \mathrm{ml})$ for the examination of cells in the aquarium tank were obtained once prior to the addition of cryptophyte prey and then again after 1 and $2 \mathrm{~h}$ following the addition of cryptophytes using a sterile serological pipette. After $20 \mathrm{~h}$, a second aliquot of cryptophytes was added to the tank ( $\sim 40 \mathrm{ml}$ of the same dense culture). Samples were then obtained 0.58 and $2.67 \mathrm{~h}$ after the second addition. The samples were drawn from within the dense patch (judged by visual inspection) using a sterile $10 \mathrm{ml}$ serological pipette and placed into $50 \mathrm{ml}$ Corning centrifuge tubes and preserved in glutaraldehyde (final conc. $0.5 \%$ ). Slides were prepared for examination under the epifluorescence microscope. An aliquot of 0.5 to $2 \mathrm{ml}$ of the fixed sample was filtered through a $0.2 \mu \mathrm{m}$ ( $25 \mathrm{~mm}$ diameter) black polycarbonate membrane filter and mounted onto a glass slide. A drop of Type FF immersion oil was added to the filter, and a glass cover slip was mounted on top. The slide was examined at $400 \times$ magnification, and a minimum of 900 cells was enumerated (with and without cryptophytes attached).

In the second time series experiment (using red water from Desdemona Sands), $\sim 40 \mathrm{ml}$ of a dense culture of Geminigera cryophila (328000 cells ml-1) was added to $\sim 161$ of Mesodinium rubrum red water, similar to the first experiment. However, in the second experiment, cryptophytes were added directly to the densest part of the $M$. rubrum patch $(5136 \pm$ 4120 cells ml ${ }^{-1}$ in the patch within the tank). Again, sampling was conducted prior to the addition of cryptophyte prey. It should be noted that densities of

Table 2. Abundances of Mesodinium rubrum and Teleaulax-like cryptophytes $>5 \mu \mathrm{m}$ at the time of collection (dd/mm/yy; in parentheses) and just prior to the beginning of the experiments (ca. $20 \mathrm{~h}$ after sample collection) for red-water patches observed in Youngs Bay and Desdemona Sands. Error estimates represent 1 SD of the mean of duplicate samples

\begin{tabular}{|lccccc|}
\hline Bloom patch site & \multicolumn{2}{c|}{ Initial collection (cells ml ${ }^{-1}$ ) } \\
& M. rubrum & Cryptophytes & \multicolumn{2}{c|}{$\begin{array}{c}\text { Beginning of experiment }\left(\text { cells ml }{ }^{-1} \text { ) }\right. \\
\text { C. rubrum }\end{array}$} & Cryptophytes \\
\hline Youngs Bay (09/28/11) & $1526 \pm 71$ & $10 \pm 3$ & $1983 \pm 1464$ & $1 \pm 1$ \\
Desdemona Sands (10/06/11) & $541 \pm 175$ & $9 \pm 5$ & $5136 \pm 4120$ & $0 \pm 1$ \\
\hline
\end{tabular}


M. rubrum were not uniform, and therefore, volumetric estimates of abundance (i.e. number per $16 \mathrm{l}$ ) would not accurately represent the true density throughout the tank. Sub-sampling from the densest part of the patch was conducted at 1.5, 3, and $5 \mathrm{~h}$ following the addition of cryptophytes, and the samples $(\sim 40 \mathrm{ml})$ were fixed in glutaraldehyde (final conc. $0.5 \%$ ) in $50 \mathrm{ml}$ plastic Corning centrifuge tubes.

\section{RESULTS}

\section{Fluctuations in field populations of cryptophytes and Mesodinium rubrum in a peripheral bay}

Ilwaco harbor in Baker Bay is thought to be the initiation site for massive, recurring blooms of Mesodinium rubrum in the Columbia River estuary (Herfort et al. 2011b). Therefore, a time series of field observations was carried out there to determine if there was a relationship between prey availability and $M$. rubrum population growth that might help to explain why the lateral bays might be initiation sites for the blooms. A time series of counts of cryptophytes and $M$. rubrum was conducted, beginning before the onset of the late-summer $M$. rubrum bloom (with sampling beginning in mid-August 2011) and continuing until after the bloom declined at the end of October 2011 (Fig. 2). Prior to the onset of the red-water bloom (on September 1, 2011), the cell densities of $M$. rubrum at the water surface were $<6$ cells $\mathrm{ml}^{-1}$. Within $2 \mathrm{wk}, M$. rubrum densities were $>8000$ cells $\mathrm{ml}^{-1}$. The high density of $M$. rubrum did not persist in Baker Bay; 1 wk later, $M$. rubrum abundances had declined to 87 cells $\mathrm{ml}^{-1}$.

A variety of cryptophyte taxa were observed at Ilwaco harbor; they were divided into 2 categories, $>5 \mu \mathrm{m}$ and $\leq 5 \mu \mathrm{m}$. Taxonomic descriptions of the cryptophytes will be reported elsewhere (B. Li et al. unpubl. data). The smaller 'Teleaulax-like' cryptophytes $(\leq 5 \mu \mathrm{m})$ were generally more abundant than Mesodinium rubrum during the bloom initiation phase (early September) and up to the decline phase (October 6 to 27, 2011). After the end of September, abundances of both cryptophytes $\leq 5 \mu \mathrm{m}$ and $M$. rubrum declined in Ilwaco harbor. In contrast, abundances of cryptophytes $>5 \mu \mathrm{m}$ exceeded those of $M$. rubrum (>150 cells $\mathrm{ml}^{-1}$ compared to 6 cells $\mathrm{ml}^{-1}$ ) only prior to bloom initiation in early September. An increase in the abundance of larger cryptophytes was observed $\sim 1 \mathrm{wk}$ prior to a second small increase in $M$. rubrum observed on September 28, 2011 (Fig. 2), but the larger cryptophytes were

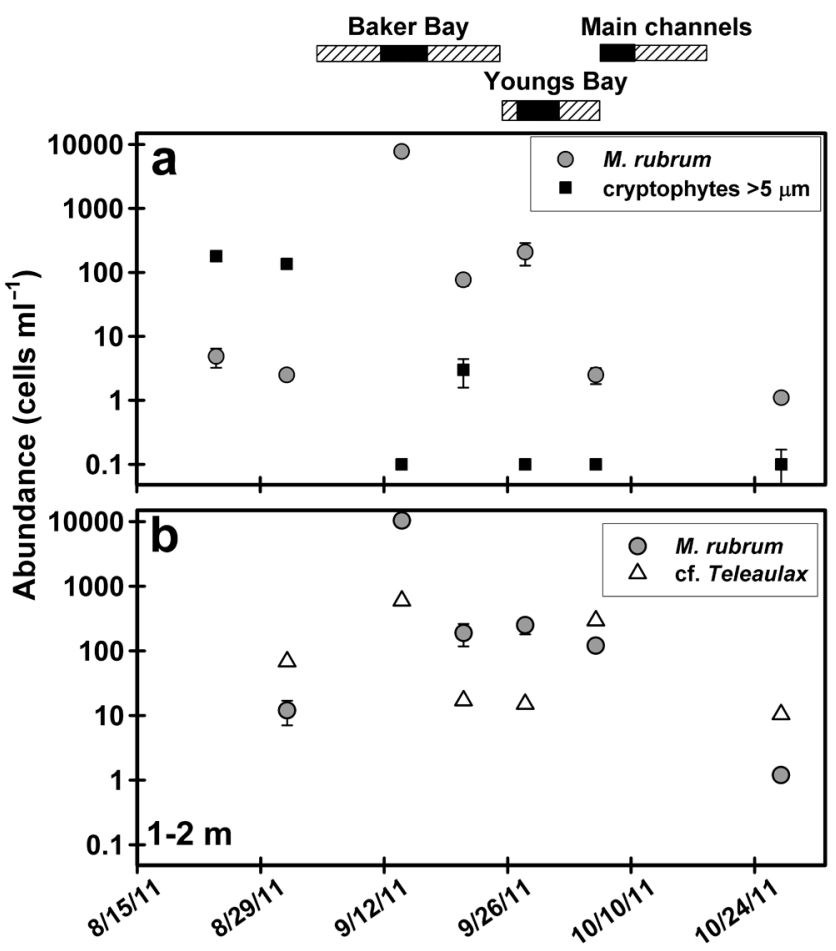

Fig. 2. Time series of observations of the abundance of cryptophytes and Mesodinium rubrum (in cells $\mathrm{ml}^{-1}$ ) at (a) the surface and (b) 1 to $2 \mathrm{~m}$ at Ilwaco Harbor in Baker Bay, Columbia River estuary, in 2011. Error bars represent \pm 1 standard deviation of the mean (where they are not visible, the error bars are smaller than the symbols, except for cryptophytes $\leq 5 \mu \mathrm{m}$, ie. cf. Teleaulax, in (b), where error estimates are not available). Note that the abundances are shown in log scale; in this figure, abundances of 0 (below detection) are shown as 0.1 for ease of visualization. The periods corresponding to observations of the $M$. rubrum bloom patches are shown above as black bars. Hatched bars surrounding the black bars represent uncertainty in the timing of bloom initiation and demise. Panel (b) shows a time series of counts of $M$. rubrum and cryptophytes determined at a depth of 1 to $2 \mathrm{~m}$ below the sea surface, demonstrating vertical patchiness

less abundant than $M$. rubrum at that time (September 21). After September 21, cryptophytes $>5 \mu \mathrm{m}$ were no longer detected in the surface waters of Baker Bay, although cryptophyte densities at 1 to $2 \mathrm{~m}$ depth were substantially higher than at the surface (Fig. 2). The inverse relationship between the larger cryptophytes and $M$. rubrum may be reminiscent of water mass exchange rather than predation; that is, the transport of a water mass with high abundances of the larger cryptophytes could precede the proliferation of $M$. rubrum if that water mass also bore, for example, high nutrient concentrations or some other characteristic conducive to $M$. rubrum growth. In contrast, the nearly simultaneous 
fluctuations in $M$. rubrum and smaller Teleaulaxlike cryptophytes may be more indicative of a predator-prey relationship.

\section{Morphological characteristics and Mesodinium rubrum-cryptophyte associations in red-water samples}

Examination of the cells revealed that-as is typical of Mesodinium rubrum from a wide variety of oceanographic environments - the cells were full of phycoerythrin-rich chloroplasts originating from the cryptophyte prey during the bloom periods. $M$. rubrum specimens from the Columbia River estuary bore the characteristic cryptophyte-derived chloroplasts, which exhibit autofluorescence when examined under the epifluorescence microscope. Redwater samples were examined live in order to observe the morphology and jumping behavior of $M$. rubrum. The cells jumped in the characteristic motion with episodic bursts of very rapid movement. During red-water blooms in 2009, 2010, and 2011, it was repeatedly noted that several of the $M$. rubrum cells had multiple attached cryptophytes on their cirri (Fig. 3a), particularly within the peripheral bays. In contrast, samples taken from red-water patches in the estuary proper showed little evidence of cryptophyte attachment (Fig. 3b), although it should be noted that the latter sites were sampled less frequently than the peripheral bays. The attached cells were confirmed as cryptophytes through the characteristic orange fluorescence viewed under epifluorescence microscopy (data not shown). The attached cells were similar to cryptophytes not only in pigmentation but also in morphology: they were often distinctly teardrop-shaped (Fig. 4). Interestingly, cells bearing cryptophytes attached to their cirri did not exhibit the characteristic jumping motion but instead undulated the cirri in unison in a slow motion (see Supplement at www.int-res.com/articles/suppl/ a068p117_supp/) and drifted slowly.

The time series of observations at Ilwaco harbor in Baker Bay indicated that the percentage of Mesodinium rubrum specimens bearing attached cryptophytes reached a peak $(\sim 30 \%$, Table 1$) \sim 1$ wk after the peak abundance of $M$. rubrum (Table 2). At Ilwaco harbor, the percentage of cells with attached cryptophytes was low prior to the onset of the bloom and after its decline. The percentages were low both within the bloom patches observed in Youngs Bay and over Desdemona Sands in the estuary proper (3.5 and $0.45 \%$, respectively, Table 1 ).
Oral tentacles were clearly visible in some specimens (Fig. 4), particularly among those observed in the estuary's main channels. Notably, there was considerable variability in the morphology of Mesodinium rubrum specimens (Figs. 3 \& 4), some of them bearing a close resemblance to the newly described small benthic form $M$. chamaeleon (Moestrup et al. 2012; Fig. 4i-k) and others to the newly defined large species M. major (Garcia-Cuetos et al. 2012). Similar to $M$. major, we observed that many of the Columbia River estuary specimens were present in a 'medusa' form.

\section{Laboratory time series observations of Mesodinium rubrum-cryptophyte associations}

During field sampling in 2011, water was collected from visible surface red-water patches in the Columbia River estuary. Densities of Mesodinium rubrum ranged from (mean \pm SD) $1526 \pm 71$ to $541 \pm 175$ cells $\mathrm{ml}^{-1}$ in the initial samples collected in Youngs Bay and Desdemona Sands, respectively, and from $1983 \pm$ 1464 to $5136 \pm 4120$ cells $\mathrm{ml}^{-1}$ in the aggregations that formed within the tanks $1 \mathrm{~d}$ after the samples were collected from Youngs Bay and Desdemona Sands, respectively (Table 2). These differences reflect the concentrating effect of aggregation within the tank in each of the 2 experiments, whereby $M$. rubrum was concentrated by $\sim 10$-fold in the Desdemona Sands experiment but only 1.3-fold in the Youngs Bay experiment between the time of collection and the time of sampling the next day (Table 2), not accounting for changes in abundance due to growth. The abundances of Teleaulax-like cryptophytes were low at the time of collection as well as at the beginning of the experiment.

We examined putative prey capture by Mesodinium rubrum (as indicated by the accumulation of cryptophytes on the cirri) during 2 laboratory-based time series studies using samples obtained from the red-water patches. A comparison between the numbers of $M$. rubrum cells bearing attached cryptophytes found before and after the Geminigera cryophila prey were added revealed a marked increase in attachment following the addition of prey. In both the Youngs Bay bloom experiment and the Desdemona Sands bloom experiment, the proportional number of $M$. rubrum with attached cryptophytes increased in a matter of hours (Table 3).

A wide range in the number of attached cells was observed (1 to >50), with typical numbers (represented by the mean and median) being higher in the 
a

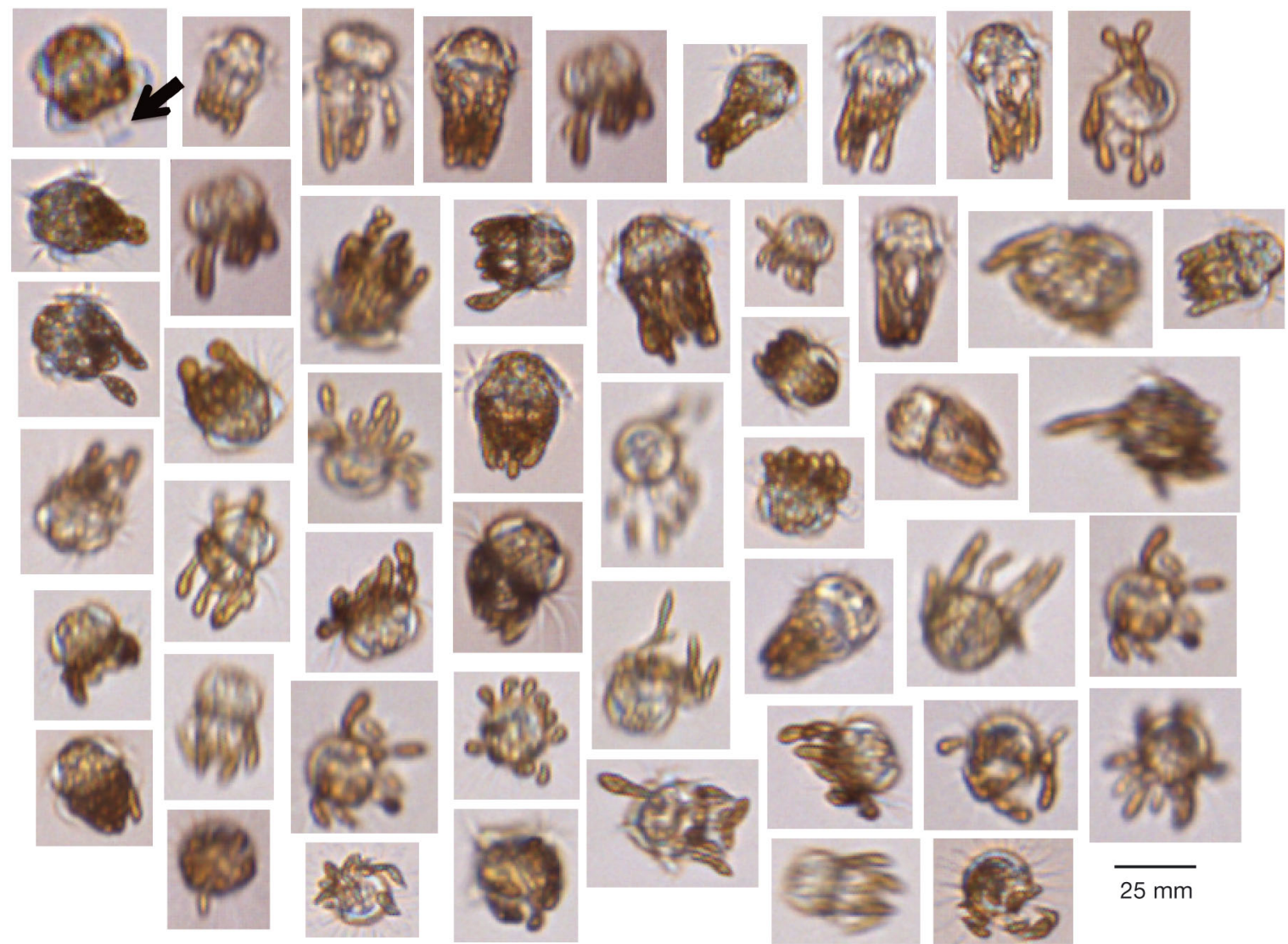

b

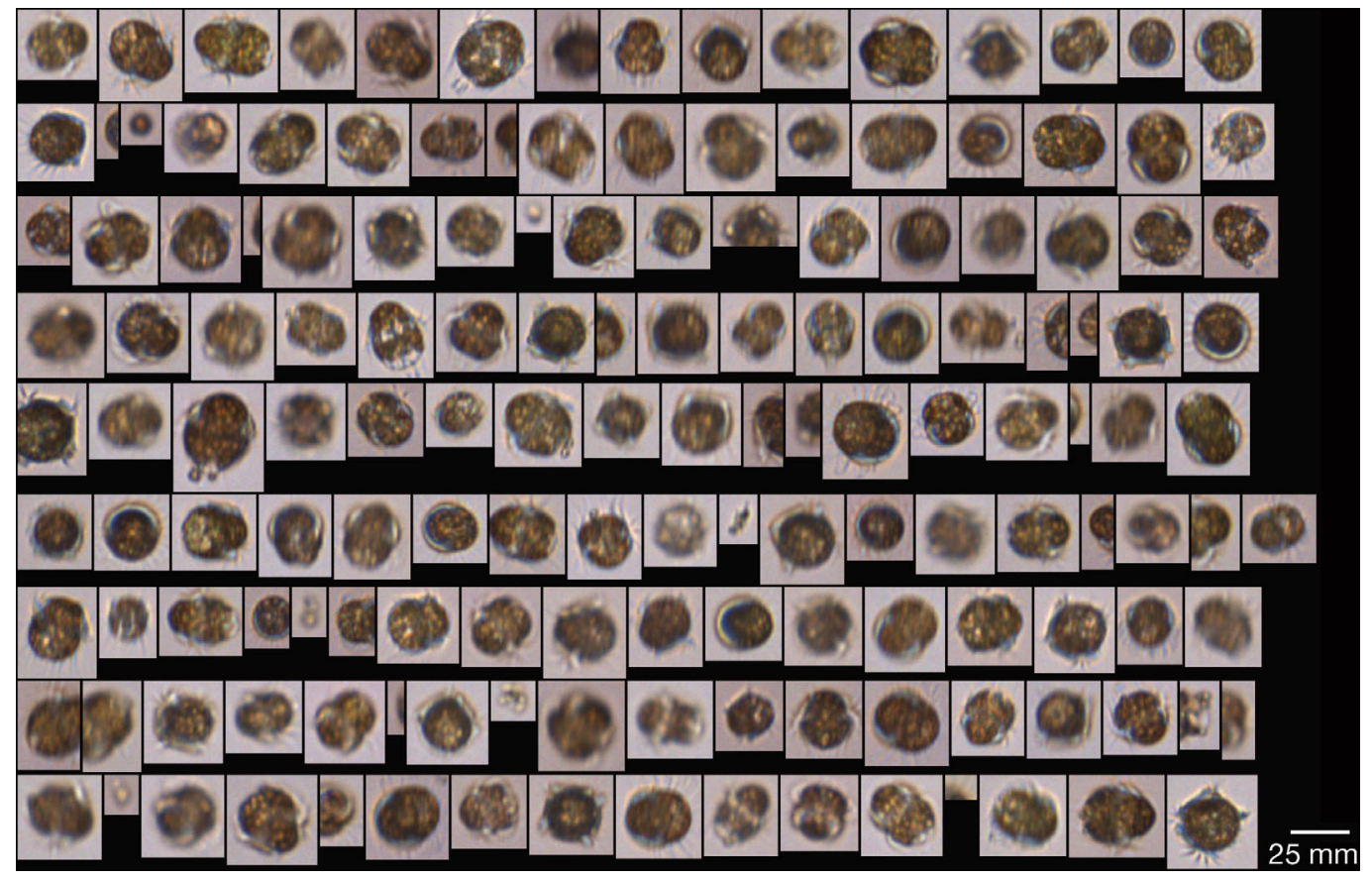

Fig. 3. (a) Images acquired using an imaging flow cytometer (FlowCAM) showing live Mesodinium rubrum specimens bearing cryptophytes attached to the cirri. All specimens came from Ilwaco harbor (September 2011); the arrow shows oral tentacles. (b) Live M. rubrum specimens shown without attached cryptophytes. These specimens were observed in the estuary proper, outside of the peripheral bays, during the 2011 red-water bloom. Note that the images in (a) were captured in different image collages and then collated (i.e. the specimens were not imaged in the sequence shown), while in (b), the images form 1 image collage (i.e. the specimens were imaged in the sequence shown). The cell diameters in (a) and (b) ranged from 15 to $40 \mu \mathrm{m}$. For each collage, the images are shown at the same size scale; therefore, apparent differences in size reflect real size differences. 

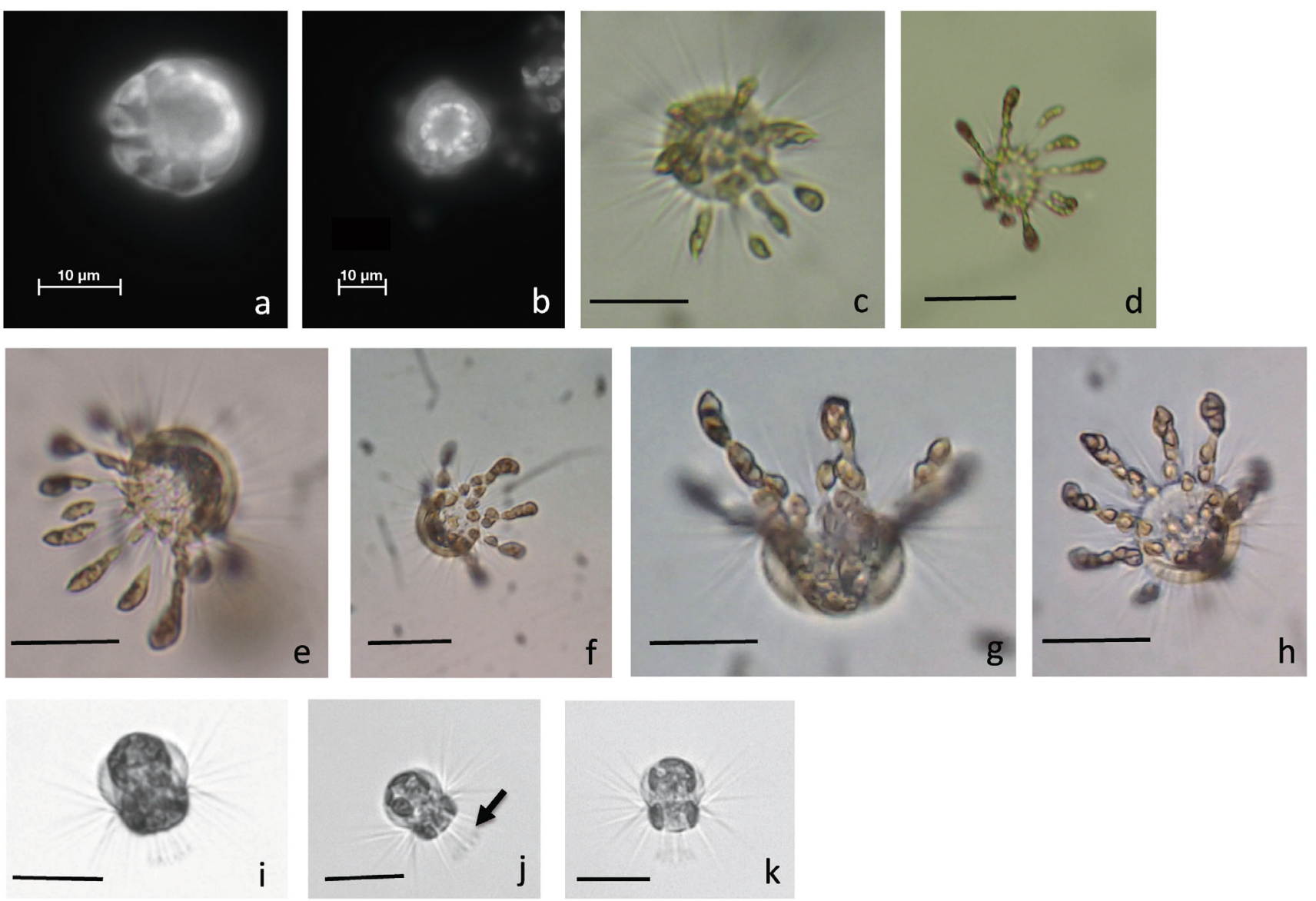

Fig. 4. Series of images showing the attachment of cryptophytes to the equatorial cirri of Mesodinium rubrum specimens. (a,b) Epifluorescence images showing phycoerythrin-rich cells (brightest areas) near the oral hemisphere, with an open space in the middle. These specimens originated from Youngs Bay in September 2011. (c-h) Images clearly showing that the attached cells are teardrop-shaped, characteristic of cryptophytes (cells from Ilwaco harbor, September 2011). (i-k) Images showing the bifurcated oral tentacles (indicated by the arrow in $\mathrm{j}$ ). These specimens were obtained from the estuary main channels in October 2011. The scale bars in (c-k) represent $25 \mathrm{~mm}$.

Table 3. Descriptive statistics showing the percentage of Mesodinium rubrum $( \pm 1 \mathrm{SD}$ of the mean of duplicate samples) bearing attached cryptophytes in 2 time series data sets; from Youngs Bay, a peripheral bay in the lower Columbia River estuary (collected on September 28, 2011), as well as Desdemona Sands, located between the estuary's 2 main channels

(collected on October 7, 2011). Median number and range (min. to max.) of cryptophytes per cell are also given

\begin{tabular}{|lcccccc|}
\hline Site & $\begin{array}{c}\text { Date of } \\
\text { experimental } \\
\text { time points } \\
(\mathrm{mm} / \mathrm{dd} / \mathrm{yy})\end{array}$ & $\begin{array}{c}\text { Sampling } \\
\text { time }\end{array}$ & $\begin{array}{c}\text { Time since } \\
\text { addition of } \\
\text { prey }\end{array}$ & $\begin{array}{c}\text { \% rubrum } \\
\text { with attached } \\
\text { cryptophytes }\end{array}$ & $\begin{array}{c}\text { Mean no. } \\
\text { cryptophytes } \\
\text { per M. rubrum }\end{array}$ & $\begin{array}{c}\text { Median no. } \\
\text { and range of } \\
\text { cryptophytes } \\
\text { per } M \text {. rubrum }\end{array}$ \\
\hline Youngs Bay & $09 / 29 / 11$ & $14: 30$ & $T_{0}$ & $2.4 \pm 2.2$ & $2.9 \pm 2.0$ & $3(1-8)$ \\
Youngs Bay & $09 / 29 / 11$ & $15: 30$ & $1 \mathrm{~h}$ & $36.4 \pm 26.5$ & $9.7 \pm 9.2$ & $5(1-27)$ \\
Youngs Bay & $09 / 29 / 11$ & $16: 45$ & $2 \mathrm{~h}$ & $39.7 \pm 16.8$ & $15.1 \pm 12.9$ & $12(1-42)$ \\
Youngs Bay & $09 / 30 / 11$ & $11: 15$ & $21 \mathrm{~h}^{\mathrm{a}}$ & $44.2 \pm 7.4$ & $13.5 \pm 11.1$ & $9(2-49)$ \\
Youngs Bay & $09 / 30 / 11$ & $13: 20$ & $23 \mathrm{~h}^{\mathrm{a}}$ & $59.5 \pm 8.4$ & $18.2 \pm 14.0$ & $12(3-53)$ \\
Desdemona Sands & $10 / 07 / 11$ & $11: 45$ & $T_{0}$ & $4.3 \pm 0.2$ & $4.4 \pm 6.4$ & $2(1-31)$ \\
Desdemona Sands & $10 / 07 / 11$ & $13: 20$ & $1.5 \mathrm{~h}$ & $16.9 \pm 2.7$ & $5.5 \pm 5.4$ & $4(2-29)$ \\
Desdemona Sands & $10 / 07 / 11$ & $14: 40$ & $3 \mathrm{~h}$ & $56.0 \pm 3.8$ & $6.7 \pm 4.4$ & $6(1-18)$ \\
Desdemona Sands & $10 / 07 / 11$ & $16: 15$ & $5 \mathrm{~h}$ & $49.2 \pm 18.2$ & $4.8 \pm 3.5$ & $4(1-13)$ \\
a A second aliquot of cryptophyte prey was added at $10: 40 \mathrm{~h}$ on $09 / 30 / 11$ & & & \\
\hline
\end{tabular}




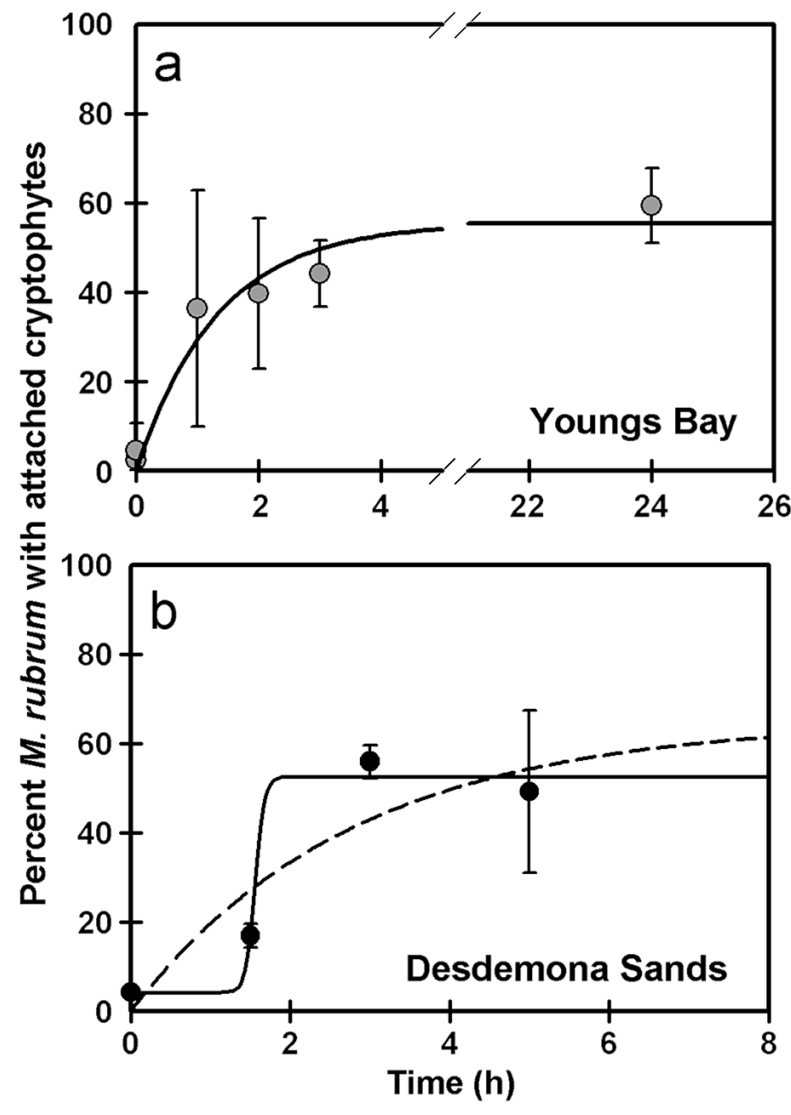

Fig. 5. Percentage of $M$. rubrum cells bearing attached cryptophytes over time in 2 laboratory time series experiments where red water was collected in (a) Youngs Bay and (b) Desdemona Sands. In (a), the points are fitted to the Ivlev model as modified by Parsons et al. (1967), with an $\mathrm{R}^{2}$ value of 0.984 and a standard error (SE) of the estimate of 5.79 ; in (b), the dotted line represents the Ivlev model fit (Ivlev 1955), while the solid line is a 3-parameter sigmoidal fit to the data $\left(\mathrm{R}^{2}=0.993, \mathrm{SE}\right.$ of the estimate $\left.=6.39\right)$

Youngs Bay tank experiments compared to the Desdemona Sands experiment (Table 3). While the mean number of attached cryptophytes increased within $2 \mathrm{~h}$ in the Youngs Bay experiment, little change was observed in the Desdemona Sands experiment over time. Due to the fact that the Mesodinium rubrum cells were present in distinct aggregations, the resulting concentrations may be less meaningful for comparisons than the proportion of the population that bore attached cryptophytes. The proportion of $M$. rubrum cells bearing attached cryptophytes increased to a saturation point between 50 and $60 \%$ in both experiments (Table 3, Fig. 5). In both experiments, small free-living cryptophytes $(\leq 5 \mu \mathrm{m})$ were still present even after the percentage of $M$. rubrum with attached cryptophytes had reached a maximum (data not shown).

\section{DISCUSSION}

Elucidating the role of cryptophytes in the feeding ecology of Mesodinium rubrum is important because it may help to explain bloom phenomena in this organism and because feeding behavior may differ among closely related species or variants. While their ability to swim rapidly and vertically migrate likely contributes to their ability to be retained in wellflushed systems, such as the Columbia River, other studies have demonstrated that $M$. rubrum show elevated growth rates when supplied with prey (Gustafson et al. 2000), and they appear to require feeding at least every 30 (Johnson et al. 2007) to $50 \mathrm{~d}$ (Smith \& Hansen 2007). This suggests that prey availability could play an important role in the dynamics and intensity of blooms of this species, which itself is a prey item for the harmful algal genus Dinophysis (Park et al. 2006, 2008).

A direct relationship between the dynamics of cryptophyte populations and Mesodinium rubrum in the field has not been reported. However, microscopic observations of $M$. rubrum specimens revealed that morphological changes occur immediately preceding and during red-water events in some individuals in the Southampton estuary (Crawford 1993). Crawford (1993) noted that in live cells, the oral hemisphere became irregular, and that some cells developed a series of finger-like projections around the circumference of the cell. 'Packages' of endosymbiont chloroplasts (confirmed by epifluorescence microscopy to show orange autofluorescence characteristic of cryptophytes) appeared to be attached to the cells. Preserved samples showed the same set of morphological variations. Changes in the oral hemisphere were noted, which were interpreted as potential budding or fragmentation of the cell since they exhibited the characteristic fluorescence of phycoerythrin-rich chloroplasts and the cells were reported to have a somewhat distorted appearance. Furthermore, free-swimming 'fragments' of larger cells were observed. It is quite possible that the freeswimming fragments they observed were cryptophytes; we therefore view these observations as consistent with our interpretation that $M$. rubrum actively harvests cryptophyte prey in the field. The irregular cells observed by Crawford (1993) were normal in terms of their swimming behavior, although it was noted that they were more fragile, perhaps resulting from 'an even higher degree of cytoplasmic vacuolation than that already noted for the species' (p. 977) in other studies (Taylor et al. 1971, Hibberd 1977, Lindholm et al. 1988). Interest- 
ingly, during our attempts to isolate $M$. rubrum cells for the initiation of cultures, the cells were observed to be very fragile; those collected from Desdemona Sands in October 2011, toward the end of the bloom phase, burst very easily as soon the water level around them became low, which is consistent with observations by Crawford (1993). We did not note a systematic change in the average cell size of $M$. rubrum over the development of the bloom in Ilwaco harbor. Differences in specimen diameter $(n=15)$ at each time point were non-significant according to a 1 -way ANOVA ( $\mathrm{p}=0.0887$ ), and average diameters ranged from 25.5 to $28.7 \mu \mathrm{m}$; however, during the bloom phase at Ilwaco harbor in Baker Bay, the range of cell sizes seemed to be broader than at other times during bloom development (15 to $40 \mu \mathrm{m}$ ). Specimens bearing attached cryptophytes were neither larger nor smaller than other cells.

We observed the presence of cryptophytes attached to the cirri of Mesodinium rubrum in Baker Bay $(\sim 4 \%$; Table 1$)$, the putative initiation site for the annual red-water blooms (Herfort et al. 2011b). During bloom development in Ilwaco harbor (Baker Bay), specimens bearing attached cryptophytes increased from 4 to $\sim 30 \%$. During the early phase of the bloom, only $0.63 \%$ of $M$. rubrum were observed to have cryptophytes attached. However, during the later phase of the bloom, attachment was common ( 20 to $30 \%$ of $M$. rubrum specimens). We did not detect attachment of cryptophytes in $M$. rubrum specimens from a post-bloom sample collected on October 6, 2011, in Ilwaco harbor. When the red-water bloom was found in Youngs Bay, the prevalence of attached cryptophytes was $\sim 3.5 \%$, whereas when red waters were located over Desdemona Sands, the prevalence was $\sim 0.45 \%$. Since we do not have observations from the later phases of the bloom, we cannot confirm whether this number increased as it did in the Ilwaco harbor (Baker Bay) time series study. In our set of observations, the attachment phenomenon appeared to be more rare in the estuary proper compared to the peripheral bays; however, the number of samples with which comparisons could be made was small. We hypothesize that active prey acquisition and feeding is spatially focused in the peripheral bays where cryptophyte populations may be larger, but this will need to be confirmed through further study.

The repeated observation of numerous cryptophytes attached to the cirri of Mesodinium rubrum specimens between 2009 and 2011 (Figs. 3a \& 4) supports the idea that they actively feed on cryptophyte prey in the field. The fact that we observed the cells with attached cryptophytes repeatedly between
2009 and 2011 suggests that the phenomenon may be common and widespread. If the attachment and capture of cryptophytes is a precursor to feeding, however, the process does not appear to be identical to that observed in the laboratory for temperate Korean M. rubrum isolates (Yih et al. 2004). Yih et al. (2004) observed the cells in $\sim 10 \mathrm{~h}$ of video as they captured cryptophyte prey, ceased movements, and guided the cryptophyte prey toward the rudimentary cytostome. The entire process from capture to ingestion and incorporation of the cryptophyte toward the aboral end of the ciliate took $\sim 92 \mathrm{~s}$. The attachment of multiple cryptophytes to the cirri of $M$. rubrum in the field observations was not apparent in these culture studies.

The laboratory time series of observations of redwater cells in the present study demonstrated that upon the addition of cryptophyte prey, greater numbers of Mesodinium rubrum bore cryptophytes attached to the cirri. The attachment or 'capture' behavior could be related to prey availability since the addition of prey in the present study resulted in an increased frequency of attachment in the population. However, in the field samples, attachment frequency appeared to increase as the bloom in Ilwaco harbor developed, suggesting that the aggregation behavior of $M$. rubrum may be implicated in cryptophyte acquisition. An increase in mean prey concentration was related to an increase in specific growth rates in Korean isolates of $M$. rubrum, up to a maximum of $0.521 \mathrm{~d}^{-1}$ (Yih et al. 2004). Without the addition of cryptophyte prey, the specific growth rate of this isolate was $0.357 \mathrm{~d}^{-1}$, demonstrating that the consumption of prey has the potential to boost cell growth of $M$. rubrum. Notably, the maximum specific growth rate at Ilwaco harbor was $\sim 4 \mathrm{~d}^{-1}$ outside of red-water patches, or 7 - to 11-fold higher than that of Korean isolates (Herfort et al. 2011b).

Although a variety of free-living cryptophytes were found within lateral bays of the estuary prior to Mesodinium rubrum blooms in 2010 (L. Herfort unpubl. data) and 2011 (present study), upon bloom initiation ( September 14), Teleaulax-like cryptophytes (i.e. similar in size and morphology) were present at higher abundance than larger taxa at Ilwaco harbor in Baker Bay. Once the M. rubrum bloom became established in Ilwaco harbor, the Teleaulax-like cryptophytes showed a corresponding decrease in abundance. The coincidence in timing between the decline in cryptophytes and an increase in M. rubrum abundances within peripheral bays suggests heavy predation by $M$. rubrum or other zooplankton consumers. There are certainly other species of 
heterotrophic ciliates and zooplankton present in Baker Bay (T. Peterson unpubl. data) that could consume cryptophyte prey; however, the coincidence between $M$. rubrum bloom initiation and development and the decline of cryptophytes is notable. No other planktonic organisms reach the abundances that $M$. rubrum does in the Columbia River estuary. Elsewhere, it has been demonstrated that in order to sustain maximum growth rates, at least 1 cryptophyte per $M$. rubrum must be ingested per day (Hansen \& Fenchel 2006). Throughout the bloom, this criterion appears to have been satisfied. The rapid decline in both $M$. rubrum and Teleaulax-like cryptophytes at Ilwaco harbor between the end of September and early October indicates either a flushing of the system or a significant decline in cryptophyte populations that could have become limiting to $M$. rubrum growth, although Teleaulax-like cryptophytes appeared to always be present in excess of $M$. rubrum (however, it should be noted that taxonomic assignment could not be confirmed through observations using light microscopy). We hypothesize that preferred prey availability could play an important role in bloom initiation, longevity, and patchiness in space and time and that the capture of multiple cryptophyte prey at once may be advantageous to $M$. rubrum in their search for prey in a dilute or patchy environment. Our observations suggest that just a meter or two below the surface, cryptophyte populations can be substantially higher than at the surface. Thus, vertical migration likely plays an important role in prey acquisition by $M$. rubrum in addition to enabling photosynthesis near the surface during daylight hours.

Experiments with temperate Korean isolates suggest that Mesodinium rubrum exhibits a feeding preference that can be fulfilled by several members of the Cryptophyceae with close taxonomic affiliation (Park et al. 2007). The morphological similarity of the cryptophytes observed at Ilwaco harbor to Teleaulax is consistent with the reported preference for Cryptophyceae within Clade B as reported by Park et al. (2007). The fact that only 1 cryptophyte species (Teleaulax amphioxeia, based on 18S rRNA gene sequence similarity; Herfort et al. 2011a) to date has been associated with $M$. rubrum in the Columbia River estuary suggests that a similar feeding preference may exist. However, little is known about cryptophyte population dynamics in the Columbia River estuary, and evidence of feeding in the field has not been previously reported.

The presence of Teleaulax amphioxeia was confirmed through sequence analysis of the 18S rRNA gene on samples that had been size fractionated through a $10 \mu \mathrm{m}$ filter and retained on a $1 \mu \mathrm{m}$ filter (B. Li unpubl. data). We hypothesize that the proliferation of $T$. amphioxeia or a closely related species plays an important role in Mesodinium rubrum bloom initiation, although noting that in order to confirm the identity of the cryptophytes attached to the cirri of $M$. rubrum, additional nucleic acid sequence data are required.

Prey acquisition by Mesodinium rubrum appears to be rapid. In a short-term $(1 \mathrm{~h})$ grazing experiment, Gustafson et al. (2000) observed that after only $5 \mathrm{~min}$ of exposure to Teleaulax acuta prey, $50 \%$ of $2 \mathrm{wk}$ starved $M$. rubrum cells harbored 1 cryptophyte nucleus. By 1 h, $20 \%$ of all of the $M$. rubrum cells had $\geq 3$ cryptophyte nuclei. Grazing rates were $1.3 \pm 0.03$ cryptophytes cell ${ }^{-1} \mathrm{~h}^{-1}$ in this first hour of exposure of starved cells to the cryptophytes. However, this rapid rate of prey consumption likely overestimates the true ingestion rate, which tends to be much slower. Observations by Hansen \& Fenchel (2006) indicated that, in culture, $M$. rubrum growing at $0.4 \mathrm{~d}^{-1}$ had ingestion rates of $\sim 3.5$ cryptophytes ciliate ${ }^{-1} \mathrm{~d}^{-1}$, while Yih et al. (2004) reported a maximum ingestion rate of 8.9 ciliate $^{-1} \mathrm{~d}^{-1}$. While we did not measure ingestion rates of cryptophyte prey by $M$. rubrum in the present study, we observed increases in the proportion of $M$. rubrum cells bearing prey attached to their cirri, which seem likely to be related to feeding and ingestion. Increases from (mean \pm SD) $2.4 \pm 2.0 \%$ of $M$. rubrum cells bearing attached cryptophytes to $36.4 \pm 26.5 \%$ of cells bearing attached cryptophytes were observed within $1 \mathrm{~h}$ in the Youngs Bay bloom sample, and an increase from $4.3 \pm 0.2$ to $16.9 \pm 2.7 \%$ was found in the Desdemona Sands bloom sample in $1.5 \mathrm{~h}$ (Fig. 5, Table 3). The average number of attached cryptophytes in the former case was $\sim 10$ (after $1 \mathrm{~h}$ ) and $\sim 6$ in the latter (after $1.5 \mathrm{~h}$ ). Although no obvious changes in the size of $M$. rubrum specimens were noted during this process, the process of preserving the specimens may have prevented detection of changes in cell dimensions through preservation artifacts.

Observations of the frequency of attachment in Mesodinium rubrum populations might be useful in the development of predator-prey models in this species, if it is assumed that capture is a precursor to feeding. For example, herbivore grazing is often parameterized by either a rectilinear fit to 2 straight lines, an Ivlev function (Ivlev 1955), or a MichaelisMenten type curve (Mullin et al. 1975), each describing the saturation point beyond which the provision of additional prey does not result in higher grazing rates. In each of the models, the latter part of the 
curve becomes flat as the predators reach a food quantity that is saturating and grazing is limited by some other process rather than prey capture (e.g. processing or assimilation). If $M$. rubrum is able to capture and retain several cryptophytes (up to $\sim 50$, based on our observations) prior to processing and ingestion, this might improve their ability to find and capture food in advance of prey ingestion and assimilation. This 'hunter-gatherer' behavior might give them a competitive advantage in that a new prey item could be available as soon as the last one is consumed; this would reduce the amount of time spent searching for prey items between assimilation events, each of which takes $\sim 90 \mathrm{~s}$. The data indicate that $\sim 40$ to $50 \%$ of the $M$. rubrum cells from the red water patch did not possess at least 1 attached cryptophyte despite the fact that free-living prey were still present (Table 3, Fig. 5). It is unclear why this would be the case, but it could reflect the fact that some portion of the population was not actively feeding. Alternatively, it could indicate that some of the cells had accumulated cryptophytes and already consumed them between the time points in our observations (i.e. generally at 1 to $3 \mathrm{~h}$ intervals). It is equally likely, however, that intra-species diversity, or diversity within the $M$. rubrum multi-species complex, may influence differences in prey preference or feeding behavior. This may explain why the attachment of multiple cryptophytes to $M$. rubrum cirri has not previously been reported. Clearly, further investigation is required to better understand the feeding behavior of $M$. rubrum in the natural environment, to uncover the role that diversity within the multi-species $M$. rubrum complex plays in feeding behavior, and to elucidate the role that cryptophyte prey play in bloom development and dynamics.

Acknowledgements. The authors acknowledge the assistance of C. Roegner and P. Kahn in field sampling efforts. J. Schilling kindly helped with the experimental set-up in the laboratory, and M. Gilbert assisted in assembling some of the data files. H. Simon generously permitted use of the epifluorescence microscope. This work was supported by funding from the National Science Foundation (OCE-0424602).

\section{LITERATURE CITED}

Corliss JO (1979) The ciliated protozoa: characterization, classification and guide to the literature, 2nd edn. Pergamon Press, Oxford

> Crawford DW (1989) Mesodinium rubrum: the phytoplankter that wasn't. Mar Ecol Prog Ser 58:161-174

> Crawford DW (1993) Some observations on morphological variation in the red-water ciliate Mesodinium rubrum. J Mar Biol Assoc UK 73:975-978
Crawford DW, Lindholm T (1997) Some observations on vertical distribution and migration of the phototrophic ciliate Mesodinium rubrum (= Myrionecta rubra) in a stratified brackish inlet. Aquat Microb Ecol 13:267-274

> Crawford DW, Purdie DA (1992) Evidence for avoidance of flushing from an estuary by a planktonic, phototrophic ciliate. Mar Ecol Prog Ser 79:259-265

Fenchel T, Hansen PJ (2006) Motile behavior of the bloomforming ciliate Mesodinium rubrum. Mar Biol Res 2: $33-40$

Frey BE, Small LF, Lara-Lara R (1984) Water column primary production in the Columbia River estuary. Columbia River Estuary Data Development Program, Astoria, OR

Garcia-Cuetos L, Moestrup O, Hansen PJ (2012) Studies on the genus Mesodinium. II. Ultrastructural and molecular investigations of five marine species help clarifying the taxonomy. J Eukaryot Microbiol 59:374-400

Gustafson DE, Stoecker DK, Johnson MD, Van Heukelem WF, Sneider K (2000) Cryptophyte algae are robbed of their organelles by the marine ciliate Mesodinium rubrum. Nature 405:1049-1052

Hansen PJ, Fenchel T (2006) The bloom-forming ciliate Mesodinium rubrum harbours a single permanent endosymbiont. Mar Biol Res 2:169-177

Hansen PJ, Moldrup M, Tarangkoon W, Garcia-Cuetos L, Moestrup Ø (2012) Direct evidence for symbiont sequestration in the marine red tide ciliate Mesodinium rubrum. Aquat Microb Ecol 66:63-75

Herfort L, Peterson TD, McCue LA, Crump BC and others (2011a) Myrionecta rubra population genetic diversity and its cryptophyte chloroplast specificity in recurrent red tides in the Columbia River estuary. Aquat Microb Ecol 62:85-97

> Herfort L, Peterson TD, Campbell V, Futrell S, Zuber P (2011b) Myrionecta rubra (Mesodinium rubrum) bloom initiation in the Columbia River estuary. Estuar Coast Shelf Sci 95:440-446

Herfort L, Peterson TD, Prahl FG, McCue LA and others (2012) Red waters of Myrionecta rubra are biogeochemical hotspots for the Columbia River estuary with impacts on primary/secondary productions and nutrient cycles. Estuaries Coasts 35:878-891

Hibberd DJ (1977) Ultrastructure of the cryptomonad endosymbiont of the red-water ciliate Mesodinium rubrum. J Mar Biol Assoc UK 57:45-61

Ivlev VS (1955) Experimental ecology of the feeding of fishes. Yale University Press, New Haven, CT

Jakobsen HH, Everett LM, Strom SL (2006) Hydromechanical signaling between the ciliate Mesodinium pulex and motile protist prey. Aquat Microb Ecol 44:197-206

Jay DA (1984) Circulatory processes in the Columbia River estuary. Columbia River Estuary Study Taskforce, Astoria, OR

> Jiang H (2011) Why does the jumping ciliate Mesodinium rubrum possess an equatorially located propulsive ciliary belt? J Plankton Res 33:998-1011

> Johnson MD (2011) Acquired phototrophy in ciliates: a review of cellular interactions and structural adaptations. J Eukaryot Microbiol 58:185-195

> Johnson MD, Oldach D, Delwiche CF, Stoecker DK (2007) Retention of transcriptionally active cryptophyte nuclei by the ciliate Myrionecta rubra. Nature 445:426-428

Lindholm T (1985) Mesodinium rubrum-a unique photosynthetic ciliate. Adv Aquat Microbiol 3:1-48 
Lindholm T, Lindroos P, Mork CA (1988) Ultrastructure of the photosynthetic ciliate Mesodinium rubrum. Biosystems 21:141-149

Lohmann H (1908) Untersuchungen zur Feststellung des vollständigen Gehaltes des Meeres an Plankton. Helgol Wiss Meeresunters 10:129-370

Minnhagen S, Kim M, Salomon PS, Yih W, Graneli E, Park MG (2011) Active uptake of kleptoplastids by Dinophysis caudata from its ciliate prey Myrionecta rubra. Aquat Microb Ecol 62:99-108

Moestrup O, Garcia-Cuetos L, Hansen PJ, Fenchel T (2012) Studies on the genus Mesodinium I: Ultrastructure and description of Mesodinium chamaeleon n. sp., a benthic marine species with green or red chloroplasts. J Eukaryot Microbiol 59:20-39

Mullin MM, Steward EF, Fuglister FJ (1975) Ingestion by planktonic grazers as a function of concentration of food. Limnol Oceanogr 20:259-262

Neal VT (1972) Physical aspects of the Columbia River and its estuary. In: Pruter AT, Alverson DL (eds) The Columbia River estuary and adjacent ocean waters. University of Washington Press, Seattle, WA, p 19-40

Oakley BR, Taylor FJR (1978) Evidence for a new type of endosymbiotic organisation in a population of the ciliate Mesodinium rubrum from British Columbia. Biosystems 10:361-369

> Park JS, Myung G, Kim HS, Cho BC, Yih W (2007) Growth responses of the marine photosynthetic ciliate Myrionecta rubra to different cryptomonad strains. Aquat Microb Ecol 48:83-90

Park MG, Kim S, Kim HS, Myung G, Kang YG, Yih W (2006) First successful culture of the marine dinoflagellate Dinophysis acuminata. Aquat Microb Ecol 45:101-106

Park MG, Park JS, Kim M, Yih W (2008) Plastid dynamics during survival of Dinophysis caudata without its ciliate prey. J Phycol 44:1154-1163

Editorial responsibility: Tom Fenchel,

Helsingør, Denmark
Parsons TR, Blackbourn DJ (1968) Pigments of the ciliate, Mesodinium rubrum (Lohmann). Neth J Sea Res 4:27-31

Parsons TR, LeBrasseur RJ, Fulton JD (1967) Some observations on the dependence of zooplankton grazing on the cell size and concentration of phytoplankton blooms. J Oceanogr Soc Jpn 23:10-17

Roegner GC, Needoba JA, Baptista A. 2011. Coastal upwelling supplies oxygen-depleted water to the Columbia River estuary. PLoS ONE 6(4):e18672

> Rosati G, Modeo L (2003) Extrusomes in ciliates: diversification, distribution, and phylogenetic implications. J Eukaryot Microbiol 50:383-402

Small EB, Lynn DH (1985) Phylum Ciliophora. In: Lee, JJ, Hutner, SH, Bovee, EC (eds) An illustrated guide to the Protozoa. Society of Protozoologists, Lawrence, KS, p 393-440

Smith WO, Barber RT (1979) A carbon budget for the autotrophic ciliate Mesodinium rubrum. J Phycol 15: 27-33

Smith M, Hansen PJ (2007) Interaction between Mesodinium rubrum and its prey: importance of prey concentration, irradiance and $\mathrm{pH}$. Mar Ecol Prog Ser 338:61-70

Soulsby PG, Mollowney M, Marsh G, Lowthion D (1984) The role of phytoplankton in the dissolved oxygen budget of a stratified estuary. Water Sci Technol 17:745-756

Stoecker DK, Silver MW, Michaels AE, Davis LH (1988) Obligate mixotrophy in Laboea strobila, a ciliate which retains chloroplasts. Mar Biol 99:415-423

Taylor F, Blackbourn DJ, Blackbourn J (1971) The red-water ciliate Mesodinium rubrum and its 'incomplete symbionts': a review including new ultrastructural observations. J Fish Res Board Can 28:391-407

> Yih W, Kim HS, Jeong HJ, Myung G, Kim YG (2004) Ingestion of cryptophyte cells by the marine photosynthetic ciliate Mesodinium rubrum. Aquat Microb Ecol 36: $165-170$

Submitted: April 30, 2012; Accepted: September 5, 2012 Proofs received from author(s): January 11, 2013 